The version of record of this manuscript is in press, having been accepted by Studies in Higher Education. This preprint appears as accepted by the publisher and should be cited as:

Wise, G., Dickinson, C., Katan, K. and Gallegos, M. C. (2018). Inclusive higher education governance: Managing stakeholders, strategy, structure and function. Studies in Higher Education, In press. doi:10.1080/03075079.2018.1525698

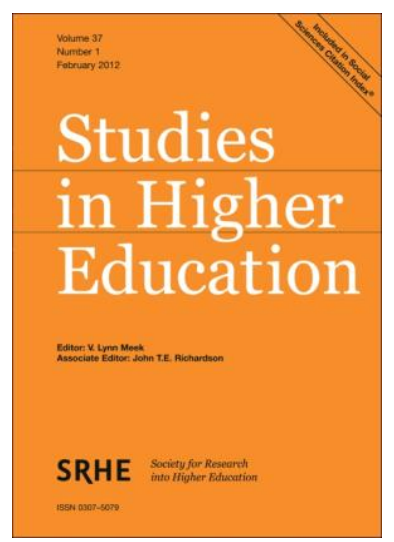

\title{
Inclusive higher education governance: managing stakeholders, strategy, structure and function.
}

\author{
${ }^{*}$ Graham Wise ${ }^{a, c}$ (ID, Connie Dickinson ${ }^{\mathrm{a}}$, Tuntiak Katan ${ }^{\mathrm{b}}$ and Maria Cristina Gallegos ${ }^{\mathrm{a}}$ \\ a Office of the Vice President of Innovation, Universidad Regional Amazónica Ikiam, Tena, Ecuador. \\ 'La Confederación de las Nacionalidades Indígenas de la Amazonía Ecuatoriana, Puyo, Ecuador. \\ ${ }^{c}$ Center for Global Health Equity, University of Wisconsin-Milwaukee, Milwaukee, WI, USA.
}

\begin{abstract}
Indigenous higher education governance is a fundamental element of diversity, equality and inclusivity at universities with significant indigenous student populations or stakeholder communities. Management approaches to establish inclusive governance mechanisms are complex and little guidance exists to support university managers to establish indigenous advisory councils. We document the creation of a university indigenous advisory council incorporating 11 indigenous nationalities. We assess the outcomes of that establishment process with the analytical lenses of participation and inclusion; accountability and rule of law; non-discrimination and equality; transparency; and mutual trust and respect. This study provides higher education policy researchers and university managers and with a clear roadmap to establish robust indigenous university governance. In doing so, we aim to empower indigenous leaders to create positive impact in higher education, contributing to high quality education and research for indigenous students and communities.
\end{abstract}

\section{KEYWORDS}

Higher education management; Indigenous governance; University diversity; Indigenous advisory council; Higher education policy

Universities are multiplex enterprises having diverse teaching, research and service missions. Universities must address the needs of students, faculty and professional staff as internal clients, as well as responding to the needs of many external government, industry and community stakeholders (Gayle, Tewarie and White 2011). A great challenge for university governance in this context of diverse accountabilities is the implementation of governance mechanisms that equitably represent and inclusively draw expertise from many diverse stakeholders across differing spheres of effect.

* CONTACT: Graham Wise, mailto:g.wise888@gmail.com, Vice President of Innovation, Universidad Regional Amazónica Ikiam. ORCID ID: 0000-0002-2958-1457. @Graham_Wise_ 
University governance structures and their interface with university management systems vary greatly across different institutions, higher education systems and countries. These governance systems have been characterized by many detailed analyses as being driven by state regulation; stakeholder guidance; academic self-governance; managerial self-governance or competition (Braun \& Merrien, 1999; Brunner, 2011; Clark, 1979; De Boer, Enders, \& Schimank, 2008; Dobbins, Knill, \& Vögtle, 2011; Mora, 2001; Schimank, Kehm, \& Enders, 1999). In the UK, the most common governance model includes an academic representative body sometimes called an academic committee or senate, and a supreme governing body or university council, primarily composed of external non-academic lay members. Over time the relative powers held by these bodies has changed dramatically in response to the marketization of universities and their need to secure a broader range of income streams (Taylor, 2013). While power is increasingly held at a university council level sometimes purportedly diminishing the role of the faculty in governance, there also is recognition of the importance of the representative senate, as well as various senate committees. Together these committees assist the penetration of governance decisions throughout the university community, addressing inherent agency problems of top down board-level governance (Buckland, 2004; Shattock, 2004; Taylor, 2013).

This paradigm of shared governance translates across the many higher education governance models that exist internationally. For example, even in the US where unicameral governance by a single board of trustees is most common, governance is shared through a network of councils or committees creating multi-level, multi-actor governance to oversee the complexity of modern university functions (American Association of University Professors, 2006; Ehrenberg, 2002; Rosvosky, 1990; Taylor, 2013). The modern evolution of shared university governance through advisory councils makes it easier for universities to engage with external stakeholder groups and respond to external policy drivers at many organizational levels (Bleiklie and Kogan 2007; De Boer, Enders, and Schimank 2008).

University governance systems commonly incorporate advisory councils to address specialized purposes such as industry or community engagement. It might follow that universities that have significant indigenous student populations or indigenous stakeholder communities should consider indigenous advisory councils as a mechanism to empower their indigenous spheres of activity. Bartlett, Marshall and Marshall $(2012,334)$ have argued that establishing an "indigenous advisory council of willing, knowledgeable stakeholders" is critical for bringing together indigenous and mainstream knowledge in academic programs. The increasingly common establishment of university indigenous advisory councils may be viewed as an institutional response to the needs of indigenous stakeholders to be empowered in the delivery of higher education.

The need for indigenous advice and representation in university governance is urgent, with indigenous students vastly under represented in higher education in countries around the world, such as Australia (Behrendt et al. 2012) and Canada (Universities Canada 2015). Kuokkanen (2007) argues that indigenous inclusion programs of universities lack success because they do not engage with indigenous worldviews. While they are built to bridge mainstream and indigenous cultures, they fail to address ontological and epistemological differences, placing responsibility to adapt wholly on the indigenous student. There is a clear need to improve the way universities work for indigenous students, and a clear need for universities to adopt expert indigenous advice to do so.

Despite the importance and difficulty of integrating indigenous governance mechanisms into complex university systems, we know of no published scientific studies that evaluate and describe practical steps for indigenous advisory council establishment. This study builds on knowledge of indigenous university governance by analyzing and describing a method for establishing an advisory council to deliver good outcomes for indigenous inclusion in higher education. We hypothesize that creating an indigenous advisory council that embodies good governance principles can be achieved through a robust and relevant project development process, and we highlight four project development dimensions that we maintain are important for this purpose: strategic planning; external stakeholder engagement; organizational management; and operational implementation. 
As a case study, we use the creation of an indigenous advisory council of a university located in the Amazon because of its strong and multifaceted indigenous history and broad range of challenges. For example, the case study has 11 indigenous stakeholder nationalities, and Ecuador's public sector regulatory environment greatly constrains the possible range of management responses to the need of inclusive governance. Furthermore, this is the first example of university indigenous advisory council creation in Ecuador.

In the discussion, we assess the process for establishment of the indigenous advisory council in context with principles of participation and inclusion; accountability and rule of law; nondiscrimination and equality; transparency; and mutual trust and respect. Each of these principles were identified by indigenous participants in the establishment of the indigenous advisory board as being critical for its successful operation, the first four of which are also listed by the United Nations as being core principles of democratic governance (United Nations Development Program 2011).

This study serves as a roadmap for the creation of university indigenous advisory councils internationally. It aims to deepen the understanding of researchers and university managers regarding organizational and cultural barriers for the planning and establishment of indigenous advisory boards. Through this study we aim to empower diverse and inclusive university leadership, supporting the capacity of universities to broaden their education, research and service missions to equitably serve indigenous students, staff and external indigenous stakeholders.

\section{Materials and methods}

\section{Case study context}

The case study is an Ecuadorian public university, established in 2014 as a part of a national higher education reform process, to provide high-quality tertiary education, research and innovation in the Ecuadorian Amazon. In accordance with its remit to educate students from an Amazon catchment, in the second semester of $2017,33.7 \%$ of enrolling students self-identified as being indigenous. For the duration of this case study, the university had a unicameral governance structure, led by a five person governing board. Associated with the future transition to a representative university council, the university is establishing an international advisory council and an indigenous advisory council called the Consejo de las Nacionalidades (Consejo), which is the subject of this case study. Further characteristics of the university, its development and its operation during the period of this case study have been analyzed and published by Wise and Carrazco Montalvo (2018).

Within the Ecuadorian Amazon region there are 11 recognized indigenous nationalities: Kichwa, Shuar, Achuar, Waorani, Sapara, Andwa, Shiwiar, Cofan, Siona, Siekopai and Kijus. Each nationality has a national organization led by a president, and is represented by the Confederación de las Nacionalidades Indígenas de la Amazonia Ecuatoriana (CONFENIAE). In addition, the Ecuadorian Amazon accommodates the territories of the uncontacted Tagaeri and Taromenane peoples.

\section{Procedures}

This is a qualitative mixed methodology study drawing on retrograde longitudinal data, semistructured interviews and Likert scale survey data. From November 2015 until November 2017 a detailed account of developmental activities was written, preserving the antecedents for the establishment of the Consejo up to two years prior its formal enactment. The account draws on operational planning documents, agendas and reports of forums, written communications of managers and organizers, university governing board documents and the founding terms of reference of the Consejo. Semi-structured interviews were held with members of the Consejo, and the university staff who worked to establish the Consejo, specifically to address open-ended questions on the principles of participation and inclusion; accountability and rule of law; nondiscrimination and equality; transparency; and mutual trust and respect. In support of semistructured interviews, five-point Likert scale ordinal data from surveys $(\mathrm{N}=9)$ were analyzed using 
ratiometric descriptive statistics plus or minus standard deviation, and the non-parametric MannWhitney $\mathrm{U}$ test to assess differences in central tendency between respondents.

\section{Results}

\section{Strategic planning}

Project planning documents show that formative development of the Consejo by the university began approximately two years prior to its enactment, following a long prior period of discussion by indigenous leaders and researchers on the need to promote dialogue, understanding and indigenous inclusion. Two of the primary motivating factors expressed by the indigenous proponents of the Consejo were: (1) to increase the number of indigenous students enrolled in, and graduating from universities; (2) to stimulate relevant indigenous research and increase the agency of indigenous participants in research.

The first of these goals, while difficult to achieve, is fairly transparent. Indigenous students face academic, cultural, social, economic and psychological obstacles to their successful completion of university studies. A strategic intent of the indigenous advisory council is to work with the university to develop programs to overcome barriers to indigenous participation in higher education.

The second goal is more complex and perhaps controversial. The profound differences in epistemological orientation between western and indigenous science, reviewed succinctly by Roué and Nakashima (2002), have frequently lead to a dismissal of indigenous knowledge and the diminution of indigenous research participants to that of "passive informants". Indigenous knowledge is often dismissed as being incompatible with western analytical and reductionist scientific method. As Mazzocchi $(2006,464)$ concludes, 'trying to analyse and validate traditional knowledge systems using external (scientific) criteria carries the risk of distorting such systems' and 'threatening traditional knowledge with dispossession'. The indigenous proponents of the university's Consejo as an indigenous advisory council of experts, recognized the importance of an indigenous governance mechanism to overcome cultural distance and ignorance, establishing their knowledge as a legitimate and essential contribution to scientific research. From its inception, indigenous participants wished to create the Consejo, to help change the role of indigenous scientists from passive informant to agentive collaborator. This was a strong motivating factor for indigenous participation in the project.

With these goals in mind an indigenous leader and a university professor organized the first informal planning forum on university campus in July 2015 as shown in Figure 1 . Both were keenly aware of the need to increase indigenous agency in higher education, drawing on the example of indigenous language documentation research where indigenous researchers have been centrally responsible for research design, project implementation and data interpretation (Dickinson 2010). Both were highly aware that in order to promote collaborative research, two obstacles would have to be addressed: (1) University researchers would need to see that indigenous people can be more than simple passive informants in research projects; (2) Indigenous people would need to demonstrate confidence in having a real voice in academic institutions and projects and being accepted as agentive collaborators.

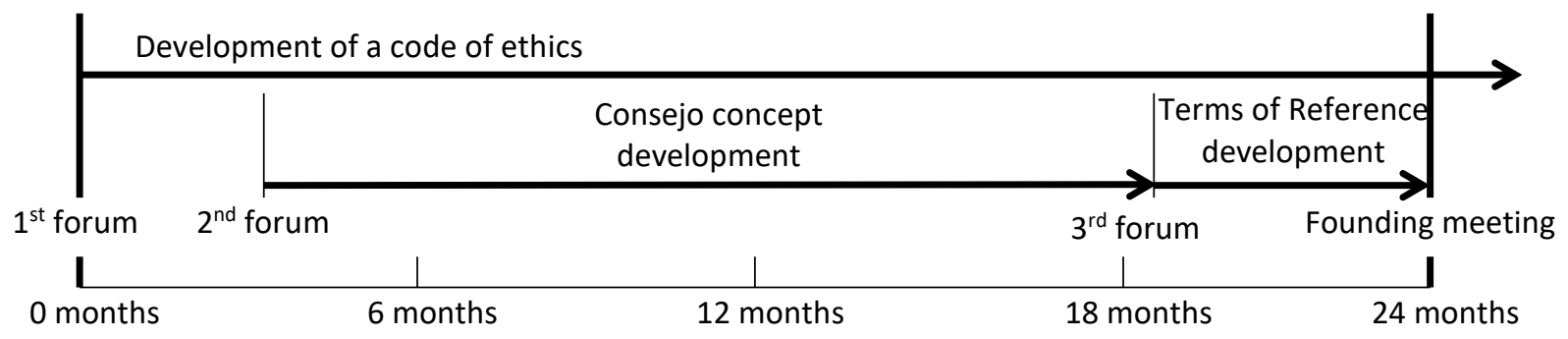

Figure 1. Timeline for development and establishment of the Consejo 
The first informal planning forum consisted of presentations on linguistics and anthropology from indigenous, national and international researchers in addition to a presentation on the relation between academics and indigenous people. The larger goal of the forum was to place indigenous researchers at the forefront of academic discussion. This goal included discussing the development of a code of ethics for indigenous research and engagement.

Three months later, a second broad planning forum was formally organized by the university specifically to advance discussion of a proposed code of ethics for indigenous research and engagement, and to propose the development of the Consejo. A call for indigenous experts to attend the meeting was announced by CONFENIAE. This call specifically highlighted the need for indigenous experts who had previously worked with universities and researchers. Leaders from nine Ecuadorian Amazon nationalities gathered with university researchers formally for the first time at this forum. Even at this early stage, discussion of the proposed Consejo was strategically focused on education, research and innovation, explicitly excluding broader political discussions such as land rights abuses and destructive expansion of extractive industries. It was known to those developing the Consejo that indigenous leaders hold much expertise, however broader recognition of this expertise was lacking. Five clear outcomes arose from the second broad forum for development of the Consejo. (1) It was demonstrated to all university attendees that indigenous leaders exist in this region who are expertly informed; politically experienced; ethical; focused positively on higher education challenges; and well versed in professional engagement with higher-education institutions. (2) It was shown that indigenous leaders from different nationalities in the region can work constructively together, overcoming community level and inter-nationality differences to express a collective indigenous world-view. (3) It was demonstrated that maintaining a focus on higher education challenges is possible, even though land rights abuses are an active and on-going concern for indigenous nationalities more broadly. (4) It was understood that it is necessary for planning meetings to be focused around a clear set of practical developmental activities, to avoid the perception of directionless talking, uncoupled from immediate action. (5) It was clear that promised actions resulting from forums must be delivered in advance of further engagement to demonstrate progress and build trust in the capability of partners to achieve outcomes.

Two years elapsed between its conception and formally convening the Consejo. This period of time was used to deliver on promised actions arising from the first, second and third planning forums. This strategic development work was undertaken with individuals and in small groups, made possible because of agreement on general concepts achieved in the broad forums.

\section{External stakeholder engagement}

We characterize the university's process of engagement with indigenous leaders as being one of slow trust building and refining of focus. Responses during semi-structured interviews revealed that while the first planning forum had a transactional intent for exchange of information and expert advice, the periods following the forum had a strong relational purpose, essential for building strong engagement between the university and indigenous leaders. For example, an interviewee responded that 'a long lead-time for development was essential for building trust and respect between indigenous leaders and the university'. The lists of invitees to development forums evidenced that whole-of-nation level engagement with indigenous stakeholders was a key strategy, working with individuals who represent their nationalities beyond local communities, and with the two iterations of the national advocacy group CONFENIAE.

The development of the code of ethics following the first planning forum, served as a practical demonstration of the university's intent to engage equitably with indigenous leaders. The code of ethics was iteratively developed as a partnership, with the university relying heavily on expert advice from indigenous leaders, and demonstrating the University's capacity to engage inclusively, empowering the broad participation of indigenous stakeholders. One interviewee reported that 'the code of ethics was a tangible activity that grounded relationship development which might otherwise have lost focus'. 
A third planning forum was held only with indigenous leaders. It was held almost six months prior to the enactment of the Consejo, and its purpose was to translate all previous developmental work into a terms of reference document that would formally define the structure and function of the Consejo once established.

Positive engagement with indigenous leaders at a national level across 11 indigenous nationalities risked creating tension with local indigenous Kichwa communities. One interviewee responded that 'local communities were concerned that their relationship with the university would be diminished by the national focus of the Consejo'. Planning for a local indigenous engagement program was prioritized, to manage the risk of perceived marginalization by local communities.

At all stages of development of the Consejo, various functional areas of the university were engaged, including the university's executive, faculty and administrational elements. This multidimensional engagement was aimed to support communication across the university's entire community. However, interviewees were divided on the effectiveness of faculty engagement. While one opinion expressed that 'everyone was given multiple opportunities to participate and with each opportunity that was provided, additional conflicting views risked derailing constructive development of the project.' Alternatively, another opinion expressed that 'the faculty does not know enough about the Consejo, more should have been done to engage the faculty.'

\section{Organizational management}

A key milestone to formalizing the establishment of the Consejo within the university community was identifying where the Consejo would be located within the university's governance structure. A review of Ecuadorian regulations confirmed the need for an advisory council rather than integration of external indigenous members within the university council. All Ecuadorian public universities have a unicameral representative university council, which does not permit external council members (Ley Organica de Educación Superior 2010). Locating the Consejo with close line of sight to the president of the university places the Consejo at the head of the university's governance structure. One respondent reflected the almost unanimous opinion that 'direct engagement between the Consejo and the rector is absolutely essential.' Oversight of the development project was by the Office of the Vice President of Innovation. This senior university leadership endorsement, having direct line of sight to the president and governing board of the university was an important factor for overcoming intra-institutional barriers to development. One respondent stated that 'without the involvement of a senior executive office bearer of the university, this project would not have happened.' Engagement with the faculty of the university was managed through a key researcher and all faculty were invited to the first and second planning workshops, held on the university campus. Subsequently, researchers were invited to contribute to the drafting of the code of ethics on four occasions during its development. While the establishment activities of the Consejo itself were managed by a small working group, broad socialization of the concept of the Consejo was started 18 months prior to its formalization. While those activities progressed, the development of the code of ethics was used as a practical tool for all faculty to contribute to an important task associated with the Consejo.

\section{Operational implementation}

The operational activities that established the Consejo followed basic project management principles for project conception, planning, execution and review. It would be uninformative to detail every activity that occurred. However the operational implementation of the Consejo is detailed in its terms of reference, which are more insightful. Listed below are the terms of reference of the Consejo that are most relevant for its operation in accordance with good governance principles.

(1) The Consejo is comprised of 11 members, one for each nationality in the Ecuadorian Amazon, the existence of two uncontacted indigenous peoples is also acknowledged. 
(2) Each nationality is given one seat on the Consejo, irrespective of relative population, territorial size, or subnational distinctions. Each nation is permitted more than one representative to share each chair. Indigenous leaders are encouraged to consider gender equity and subnational distinctions in their selection of representatives.

(3) The presidents of each indigenous nationality are entirely responsible for selecting their representatives to the Consejo. The university takes no responsibility, expresses no intent and imposes no specific system for election of representatives.

(4) Consejo members are not remunerated as university employees, preserving independence and objectivity.

(5) Consejo members are remunerated for all costs as independent agents, and receive a per diem for undertaking Consejo activities and events. The value of the per diem reflects both the costs of travel to Consejo meetings and the lost financial opportunity that Consejo members incur when spending time away from their normal earning activities.

(6) Consejo members are elected for 3-year renewable terms.

(7) The Consejo makes decisions by collective approval without vote.

(8) The Consejo meets twice per year in coincidence with the semestral university calendar in Ecuador.

(9) The Consejo reports directly to the president of the university.

(10) The Consejo may invite the president or their delegate or others to Consejo meetings. Those invitees have neither voice nor vote.

(11) The Consejo is supported by one professional staff member and one member of faculty, to facilitate direct engagement of the Consejo with staff and students of the university.

\section{Statistical analysis}

For all but two areas of questioning, there was very strong conformity $(94.5 \% \pm 7.9 \%)$ between survey respondents, who expressed agreement or strong agreement with the developmental principles of the Consejo including: Direct engagement with the university president; the need for a long developmental lead time; having a specialist higher education focus; development with national indigenous leaders; co-development with a code of ethics; being championed by a senior university leader; integration within the university governance structure; the practicality and good principles of its terms of reference; and its support for indigenous equality and inclusive governance.

However a Mann-Whitney $U$ test showed that agreement was significantly lower in two areas of questioning relating to the political associations of the Consejo and its members, and engagement with faculty during its development $(p=0.011$ and $p=0.0001$ respectively). Only $44 \%$ of respondents agreed or strongly agreed that the political engagement of the indigenous Consejo members was beneficial, while $33 \%$ of respondents agreed or strongly agreed that it was counterproductive. Furthermore, $89 \%$ of respondents disagreed or strongly disagreed that engagement with faculty was sufficient.

\section{Discussion}

Altering the governance structure of a complex organization is challenging and presents potential risk to the very fabric of the organization. Governing bodies have the power to direct the vision and mission their organizations, the authority to control organizational functions at any level, and the capacity to inspire or impose systemic culture change. Despite the risks, there is a strong need for universities to adopt indigenous governance mechanisms, where they have significant indigenous student populations or other indigenous stakeholders. Participation rates for indigenous students in education systems are low in many countries (The Department of Economic and Social Affairs 2009). In higher-education, indigenous equality gaps are best reported in Australia (Behrendt et al. 2012; Bennett et al. 2015) and Canada (Tomaszewski et al. 2011). Importantly in Australia, strategic planning to resolve higher education deficits for indigenous peoples includes the principle of 
indigenous governance in universities. For example a principle for indigenous cultural competency by the Australian Indigenous Higher Education Advisory Council is that indigenous people should be 'active in university governance, leadership and management' (Andersen et al. 2008, 9). This view is echoed in the Best Practice Framework for Indigenous Cultural Competency of the peak body for Australian higher education, Universities Australia (2011). To truly demonstrate systemic and organization-wide indigenous equality and inclusion, the governance structures of universities must include indigenous people. This principle holds true even if the faculty and professional staff of those universities already undertake their duties in a manner that embodies values of equity and inclusivity.

The timeframe of this study is acknowledged as a limitation, recognizing that additional time for the continued operation of the Consejo would be necessary to evaluate its impact, and ultimately its success over the years. Instead, this case study has established a detailed account of the strategic planning and developmental pathway for the creation the Consejo, offering insights relating to the creation of robust university indigenous advisory councils. In this discussion we analyze the development of the Consejo in context with mutual trust and respect; transparency; non-discrimination and equality; accountability and the rule of law; and participation and inclusion.

\section{Mutual trust and respect}

Viewed transactionally, universities impart authority on advisory councils and in return council members deliver expert advice within the remit of their authority. However agency theory highlights the importance of interpersonal relations in complex exchanges (Eisenhardt 1989), and relational governance modeling highlights how important relationships are for organizational governance (for example, see Zaheer and Venkatraman [1995]). The exchanges that occur between indigenous advisory councils and their host universities are certainly complex. They navigate issues of intercultural communication and cultural difference, in addition to overcoming more typical challenges inherent with governing a large, complex organization. Because of this relational context, it is essential to build mutual trust and respect between indigenous advisory council members and university office bearers. In this way, the activity of a council can be embedded more smoothly within the governing structure of a university.

While the two year development period of the Consejo was a significant period of time to invest in a development activity, it was necessary and could be considered to be just a moment in time, compared with South America's last 500 years of turbulent indigenous history. In all countries, historical injustices, cultural misconceptions and the prejudices of individuals can exist across any type of organization. These historical antecedents take significant time to reconcile in order to build trust among all parties. The long development period of the Consejo was also sufficient time for the university to iteratively deliver on progressive developmental milestones. Investing significant time into development demonstrates strong organizational commitment to enduring engagement. It dispels fears that an organization may be seeking a quick and superficial indigenous whitewashing. A long lead-time for development, allows mutual trust, respect and understanding to evolve naturally. In practice, this means natural discourses have time to mature within a multicultural development team, and to be communicated to disparate stakeholder communities. It permits time for communities to distil this information and relay responses back to the development team for incorporation in further developmental phases.

A disadvantageous corollary of a long developmental lead-time for an indigenous advisory council may be perceived indecisiveness or inaction. In this case study, the drafting of a code of ethics for indigenous research and engagement served as a practical tool to circumvent perceptions of inaction, focusing the intent and actions of the development team for the duration of development. From inception, it was recognized that a code of ethics would be an essential platform for the functioning of the Consejo, standing as an important outcome in its own right.

Since governing structures are powerful influencers of organizational vision and culture, it is essential to ensure that advisory council members have the skills and experience that are necessary 
to govern effectively. Therefore a demonstration of how indigenous expertise could be accessed was critical to establishing trust in the capability of potential Consejo members. The development period of the Consejo, provided multiple working opportunities for potential council members to demonstrate their expertise; global view; cooperative decision making capacity; education focus; and professionalism. By the end of its development, all parties had the confidence and trust in each other to know that the Consejo would be capable of delivering expert advice, and that the university would be capable of responding to that advice.

\section{Transparency}

The costs and benefits of transparency have been widely debated in context with democratic governance, for example see Stasagage (2006), highlighting that there are contrasting views regarding the value of transparency in different forms of governance. We maintain that transparent communication is essential in negotiation, where parties are developing trust and respect and must express desired shared outcomes. Transparency was especially important for the development of the Consejo, when negotiating sensitive matters or points of potential conflict. Two of the most challenging topics for negotiation during development of the Consejo were its breadth of focus, and the strength of its authority. From the outset of its development, it was made clear that the Consejo would be a council of experts having a specific focus on education, research and innovation. It was frankly acknowledged that the primary value of the university was not as a contributor to national debates on indigenous land rights or similar politically charged issues. While some delegates at the second forum for the development of the Consejo initially expressed differences of opinion, it was broadly understood and appreciated that the university's greatest value was as a champion for indigenous education, research and innovation. These acknowledgements helped guide the intent of some indigenous participants who might have preferred a broader focus. Acceptance by indigenous stakeholders of the education focus of the Consejo was a positive outcome of transparent and honest discussion.

In addition to defining the breadth of focus of the Consejo, defining the strength of its authority was also a matter for negotiation that required transparency and clear communication to resolve. It was stated clearly from the outset that the law of Ecuador did not permit external lay representatives on university councils. This admission risked creating the perception among indigenous leaders that an advisory council would lack strength as an ancillary structure. To manage this potential misconception the shared governance models of universities were explained to demonstrate that all councils together comprise the governance structure of universities. The strength of an advisory council rests in having a short line of sight to the president of the university, and in its direct engagement with the university council, the staff, and students of the university. The power dynamics of university governing structures are a subject of strong debate internationally (Bleiklie and Kogan 2007; Boffo, Dubois, and Moscati 2008; Brunner 2011; De Boer et al. 2008; Goedegebuure et al. 2009; Jones et al. 2001; Shattock 2013) and there is no single solution for the equitable distribution of power. A transparent approach to articulating legal limitations to authority is necessary to identify legally and mutually acceptable opportunities to distribute power equitably with indigenous stakeholders.

In addition to transparency in negotiation, this case study paid particular attention to the use of personal transparency. Prior to each development forum, indigenous leaders were invited to the home of the key researcher who was leading the establishment of the Consejo. While this personal form of engagement may not align with formal protocols for engagement between leaders in many countries, we view informal social gatherings as being necessary for personal transparency. We looked to CONFENIAE as a model for this type of engagement. CONFENIAE consists of 11 indigenous nationalities, speaking ten different languages who out of necessity communicate in Spanish. Some of these nationalities are traditional enemies and others are currently involved in territory disputes. CONFENIAE successfully uses informal social gatherings to bridge vast linguistic, cultural, social and political divides to form a functioning organization. Gathering together in 
informal settings allows participants from diverse linguistic and cultural backgrounds to create a shared context from which to interpret and understand the various perspectives that are presented in formal meetings.

Whilst it is expected that universities within indigenous regions deliver services to their indigenous communities, to establish an indigenous advisory council we maintain that it is important for a university to express to prospective council members that 'we need you'. The primary function of an indigenous advisory council is to provide expert insight based on an indigenous world-view. By acknowledging this need for expert advice during the development process of a council, universities can express their intent to empower indigenous leaders, acknowledging their expertise, respecting their perspectives, and requesting their assistance.

\section{Non-discrimination and equality}

Universities that sit firmly within the well-defined boundary of a single indigenous nationality have clear guidance to understand the range of indigenous groups they must work inclusively with. However, the complex indigenous territorial landscape of this case study's student catchment presented a challenging backdrop to determine principles for indigenous inclusivity. The university took a whole-of-nationality approach, engaging with leaders of nationalities, irrespective of population, territorial size or geographical proximity. In response to increasing concern of local communities that their local needs may be marginalized by national priorities, a local engagement program was also prioritized. Inclusive engagement with indigenous stakeholders across different socio-geographic scales may require the establishment of separate spaces for discourse so that local, regional and national forums for discussions can be maintained without cross-interference.

There is risk that proposals by universities to establish indigenous advisory councils can be perceived by indigenous stakeholders as cynical exercises in political correctness or legal requirement. In many countries, long histories of indigenous injustice and cultural misunderstanding exist, contributing to cynical predispositions that must be overcome. The drafting of a code of ethics for indigenous research and engagement during this case study, was a practical way for the university to demonstrate its intent and its capacity to act equitably. By working inclusively and equitably with indigenous advisors for the drafting of the code of ethics, the university demonstrated through action, its commitment to equality, and its capacity to adopt equitable work processes. The incorporation of a tangible product, requiring equitable work processes for development is a valuable tool for proving through action, the capacity of a university to work equitably with an indigenous advisory council.

In addition to the need for universities to work equitably with indigenous advisory councils, it is necessary for those councils to work equitably with their indigenous communities. An indigenous "nationality" can encapsulate a people who have a unified cultural, socio-economic and political identity (CONAIE 1989), however sub-national distinctions that may be historical legacies or consequences of geographical separation exist across many indigenous groups. For example, in the Ecuadorian Amazon, $80 \%$ of indigenous people are Kitchwa, creating a very large and diverse nationality with notable sub-national distinctiveness. The Kichwa nationality is undergoing an ongoing process of ethnogenesis, driving the emergence of new group identities through fission, fusion, and redefinition (Haley and Wilcoxon 2005; Wroblewski 2012). The solution proposed by indigenous leaders, for the Consejo to equitably manage sub-national distinctions without degrading equitability between nationalities, was to allow one voice per nationality irrespective of size or heterogeneity. However, multiple representatives are permitted on the Consejo so that each nationality can accommodate for gender and other social diversity. Despite having uneven numbers of representatives, the limit of one voice per nationality ensures that larger more diverse nationalities have no more power than smaller homogenous nationalities.

Level of remuneration of council members has a strong impact on equitability. It cannot be assumed that indigenous leaders are remunerated by their national associations for undertaking their leadership roles. For this reason it would be unethical to assume that indigenous leaders have 
the financial capacity to act as voluntary unpaid council members. In this case study, remuneration is provided to Consejo members as independent advisors, for all costs associated with Consejo activity, including lost financial opportunity for time spent away from their normal earning activities. Equitability demands that expert advisors are fairly remunerated for their services. The form of remuneration proposed in this case study provides equitable remuneration of Consejo members without compromising their independence and objectivity.

\section{Accountability and rule of law}

It is important that indigenous nationalities have the freedom to appoint their own representatives to an indigenous advisory council, so that they remain accountable for the selection process used, and so that they remain accountable for the performance of those representatives. In addition to serving the principle of accountability, the university's decision to take no formal role in the selection of representatives to the Consejo was also grounded in practicality. The practical benefit of this approach is that the processes for appointing representatives can differ between nationalities, each implementing an approach that works with the rule of law and the relevant cultural, political and practical considerations of each nationality.

Further to conceptual principles, a practical consideration to ensure accountability between an indigenous council and a university is the clear articulation of reporting processes between the parties. The terms of reference of the Consejo clearly state, how recommendations of the Consejo should be conveyed to the university, how the university should respond, and what time periods are allowable for responses. Furthermore, these accountability processes are strengthened when formalized legally. Any university that aims to establish an indigenous advisory council must carefully consider the types of regulatory mechanisms that are necessary to formalize the relationship with their council. It is admirable for a university to voluntarily choose to adopt a mechanism for indigenous engagement, however voluntary measures can be selectively applied or ignored, and can be easily rescinded over time. To ensure that the organization as a whole remains committed to its indigenous stakeholders, each university must bind the existence of its indigenous advisory council within its regulatory or management framework. In this case study, this meant approval of a governing board resolution to permit the existence of a council, further articulating its structure, internal function and communication channels with the university. Formal establishment of an indigenous advisory council sends a powerful message to its indigenous stakeholders about the university's commitment to indigenous engagement at the highest level.

\section{Participation and inclusion}

During its establishment, serious consideration was given to how the Consejo members would participate collectively, especially in relation to participatory decision making. Voting and veto mechanisms are valuable for their ability to quantify who voted for or against a council decision. However such quantification can entrench council members in opposing camps. While a motion may pass with majority vote, the council must then move forward contrary to the opinions of some of its members. It was the view of Consejo members that this process can lead to disenfranchisement of dissenting members, and can amplify transitory differences in opinion into lasting conflicts.

The members of the Consejo decided to employ a system of collective approval without voting. This system produces collective council recommendations, even though individual members may withhold differing individual opinions. The absence of voting means that there is no need for dissenters to publically declare their opposition to the majority, or publically agree with a position that they may find individually concerning. The purpose of this system it to listen to, acknowledge and accommodate different viewpoints, and to arrive at a decision that no one strongly objects to. There is heavy responsibility on proponents and dissenters of a decision, to negotiate a more moderate position. Such responsibility sharing has value in binding together council members who 
hold differing views. With such a system it is possible for a council to express a consensus and move forward, while acknowledging the continuing differential opinions of each council member.

\section{Future research directions}

While the this study is limited to the creation phase of an indigenous advisory council, it stands as a baseline for future work that night assess operational activities and impact of the Consejo. That future work would be better able to analyze correlations between the principles for council creation establishment that are addressed in this study, and their impacts on the effective operation of councils.

An interesting outcome of the creation of the Consejo was the choice of the council members to use collective approval without voting as a method for shared decision-making. This decision-making system contradicts typical western board procedures requiring majority or unanimous voting, however it may represent a form of collective decision-making that is more familiar to indigenous leaders of the region. An further evaluation of collective decision-making systems indigenous nationalities lies beyond the scope of this study but may be of interest in future.

The specific challenge of indigenous inclusion is an important element of broader cultural diversity challenges. Future studies of possible synergies or tensions between indigenous participation programs and international student recruitment programs may help to reframe our understanding of programs to improve indigenous participation within a multifaceted university context.

\section{Geolocation information}

Longitude and latitude of the study location in decimal degrees: $-0.9493649,-77.8636047$

\section{Acknowledgements}

We thank and acknowledge the members of the Consejo de las Nacionalidades of Ikiam University for their commitment to its establishment. We thank the Office of Engagement of Ikiam University for its operational support to establish the Consejo. We acknowledge the strong commitment of Ikiam's managers and governing board members, to incorporate the Consejo into Ikiam's governing structure. We applied the sequence determines credit approach for the order of authors.

\section{Disclosure statement}

No potential conflicts of interest are reported by the authors.

\section{ORCID}

Graham Wise iD , https://orcid.org/0000-0002-2958-1457.

\section{References}

American Association of University Professors. 2006. Policy documents and reports. (10th ed.), Baltimore, MD: Johns Hopkins University Press.

Andersen, Clair, Graeme Gower, Tamara Mackean, and John Maynard. 2008. "Ngapartji-Ngapartji yerra : stronger futures : report of the 3rd annual IHEAC Conference." Indigenous Higher Education Advisory Council Conference. Canberra: Indigenous Higher Education Advisory Council.

Bartlett, Cheryl, Murdena Marshall, Albert Marshall. 2012. "Two-Eyed Seeing and other lessons learned within a co-learning journey of bringing together indigenous and mainstream knowledges and ways of knowing." Journal of Environmental Studies and Sciences, 2 (4), 331-340. doi:10.1007/s13412-0120086-8. 
Behrendt, Larissa, Steven Larkin, Robert Griew, and Patricia Kelly. 2012. Review of Higher Education Access and Outcomes for Aboriginal and Torres Strait Islander People: Final Report. Canberra: Australian Government.

Bennett, A., Naylor, R., Mellor, K., Bridges, E., Brett, M., Gore, J., Harvey, A., et al. 2015. The Critical Interventions Framework Part 2: Equity Initiatives in Australian Higher Education: A Review of Evidence of Impact. Newcastle, Australia: Centre of Excellence for Equity in Higher Education.

Bleiklie, Ivar, and Maurice Kogan. 2007. "Organization and governance of universities." Higher Education Policy, 20 (4), 477-493. doi: 10.1057/palgrave.hep.8300167.

Boffo, Stefano, Pierre Dubois, and Roberto Moscati. 2008. "Changes in university governance in France and in Italy." Tertiary Education and Management, 14 (1), 13-26. doi:10.1080/13583880701814132.

Braun, D., and F. X. Merrien. 1999. "Governance of universities and modernisation of the state: analytical aspects". In Towards a New Model of Governance for Universities? A Comparative View, edited by D Braun and F. X. Merrien, 9-33. London: Jessica Kingsley. doi:10.1007/978-1-4020-6446-3_3.

Brunner, José Joaquín 2011. "University governance: Typology, dynamics and trends." Revista de Educacion, 355, 137-159.

Buckland, Roger. 2004. "Universities and industry: Does the Lambert code of governance meet the requirements of good governance?" Higher Education Quarterly, 58 (4), 14. doi:10.1111/j.14682273.2004.00272.x.

Clark, B. R. 1979. "The many pathways of academic coordination." Higher Education, 8, 251-267.

CONAIE. 1989. Las Nacionalidades Indígenas en El Ecuador: Nuestro Proceso Organizativo [The Indigenous Nationalities of Ecuador: Our Organizational Process] Quito: Confederación de Nacionalidades Indígenas del Ecuador.

De Boer, Harry, Jurgen Enders, and Uwe Schimank. 2008. "Comparing higher education governance systems in four European countries." In Governance and Performance of Education Systems, edited by N. C. Soguel and P. Jaccard, 35-54. Netherlands: Springer. doi:10.1007/978-1-4020-6446-3_3.

Dickinson, C. 2010. "Quand les Tsachila (Equateur) eux-mêmes documentent leur langue et leur culture." In Faits de Langues: Linguistique de terrain sur langues en danger - Locuteurs et linguistes, edited by C. Grinevald and M. Bert. Paris, France: Ophrys.

Dobbins, M., C. Knill, and E. M. Vögtle. 2011. "An analytical framework for the cross-country comparison of higher education governance." Higher Education, 62(5), 665-683. doi:10.1007/s10734-011-9412-4

Ehrenberg, R. G. 2002. Tuition rising: Why colleges cost so much. Cambridge, MA: Harvard University Press.

Eisenhardt, Kathleen M. 1989. "Agency Theory: An Assessment and Review." The Academy of Management Review, 14 (1), 57-74. doi:10.2307/258191.

Gayle, Dennis John, Bhoendradatt Tewarie, and A. Quinton White. 2011. Governance in the Twenty-FirstCentury University: Approaches to Effective Leadership and Strategic Management. Vol 30 (1). NJ: Jossey-Bass.

Goedegebuure, Leo, Martin Hayden, and V. Lynne Meek. 2009. “Good governance and Australian higher education: An analysis of a neo-liberal decade.: In International Perspectives on the Governance of Higher Education: Alternative Frameworks for Coordination, edited by J. Huisman, 145-160. New York: Routledge Taylor and Francis Group.

Haley, Brian D., and Larry R. Wilcoxon. 2005. "How Spaniards Became Chumash and Other Tales of Ethnogenesis." American Anthropologist, 107 (3), 432-445. doi:10.1525/aa.2005.107.3.432.

Jones, Glen A., Theresa Shanahan, and Paul Goyan. 2001. "University governance in Canadian higher education." Tertiary Education and Management, $7 \quad$ (2), 135-148. doi:10.1080/13583883.2001.9967047

Kuokkanen, Rauna. 2007. Reshaping the University: Responsibility, Indigenous Epistemes, and the Logic of the Gift. Vancouver, Canada: UBC Press.

Ley Organica de Educación Superior [Higher Education Law]. №298 Registro Oficial 2010.

Mazzocchi, F. 2006. "Western science and traditional knowledge." EMBO Reports 7 (5): 463-466. doi:10.1038/sj.embor.7400693

Mora, J. G. 2001. "Governance and management in the new university." Tertiary Education and Management, 7(2), 95-110. doi:10.1080/13583883.2001.9967044

Rosvosky, H. 1990. The University: An Owner's Manual. New York: Norton. doi:10.1080/08109029208629528

Roue, M. and Nakashima, D. 2018. "Knowledge and foresight: the predictive capacity of traditional knowledge applied to environmental assessment." International Social Science Journal 54 (173): 337-347. doi:10.1111/1468-2451.00386 
Schimank, U., B. M. Kehm, and J. Enders. 1999. "Institutional mechanisms of problem processing of the German university system: Status quo and new developments." In: Towards a New Model of Governance for Universities? A Comparative View, edited by D. Braun and F. X. Merrien, (pp. 179-194). London: Jessica Kingsley.

Shattock, Michael. 2004. “The Lambert code: Can we define best practice?” Higher Education Quarterly, 58 (4), 13. doi:10.1111/j.1468-2273.2004.00271.x.

Shattock, Michael. 2013. "University governance, leadership and management in a decade of diversification and uncertainty." Higher Education Quarterly, 67 (3), 217-233. doi:10.1111/hequ.12017.

Stasagage, David. 2006. "Does transparency make a difference? The example of the European Council of Ministers." In Transparency: The Key to Better Governance?, edited by C. Hood and D. Heald. Oxford: British Academy. doi:10.1.1.470.1804.

Taylor, Mark. 2013. "Shared Governance in the Modern University." Higher Education Quarterly, 67 (1), $80-94$. doi:10.1111/hequ.12003.

The Department of Economic and Social Affairs of the United Nations Secretariat. 2009. State of the World's Indigenous Peoples. New York: United Nations.

Tomaszewski, Andreas E., Tracy L. Powell, Cynthia Gallop, Chad London, and Sydney M. Gyles. 2011. "The university experience of underrepresented groups: The case of Aboriginal students in Canada." International Journal of Arts and Science, 4 (17), 333-344.

United Nations Development Program. 2011. "Governance principles: Institutional capacity and quality." In Towards Human Resilience: Sustaining MDG Progress in an Age of Economic Uncertainty, 268 - 288. New York: UNDP.

Universities Australia. 2011. National Best Practice Framework for Indigenous Cultural Competency in Australian Universities. Canberra: Universities Australia.

Universities Canada. (2015). Closing Canada's Indigenous education gap. Ottawa, ON: Universities Canada.

Wise, G., and I. Carrazco Montalvo. 2018. "How to build a regional university: A case study that addresses policy settings, academic excellence, innovation system impact and regional relevance." Journal of Higher Education Policy and Management. 40 (4), 342-358. doi:10.1080/1360080X.2018.1482104.

Wroblewski, Michael. 2012. "Amazonian Kichwa proper: Ethnolinguistic domain in pan-indian Ecuador." Journal of Linguistic Anthropology, 22 (1), 64-86. doi:10.1111/j.1548-1395.2012.01134.x.

Zaheer, Akbar, and N. Venkatraman. 1995. "Relational governance as an interorganizational strategy: An empirical test of the role of trust in economic exchange." Strategic Management Journal, 16 (5), 373 392. doi:10.1002/smj.4250160504 